NAVA BAR

Higher Studies Israel

\title{
DIFFICULTIES EXPERIENCED BY SPECIAL EDUCATION NOVICE TEACHERS IN THEIR INDUCTION YEAR, AT THE VARIOUS SPECIAL EDUCATION FRAMEWORKS IN ISRAEL: OUTLINE OF A RESEARCH STUDY
}

\begin{abstract}
Bar Nava, Difficulties Experienced by Special Education Novice Teachers in Their Induction Year, At the Various Special Education Frameworks in Israel: Outline of a Research Study [Trudności napotykane przez nauczycieli w edukacji uczniów ze specjalnymi potrzebami $\mathrm{w}$ pierwszym roku pracy $\mathrm{w}$ różnych systemach edukacji specjalnej w Izraelu: przyczynki do badania]. Studia Edukacyjne nr 37, 2015, Poznań 2015, pp. 377-392. Adam Mickiewicz University Press. ISBN 978-83-232-0000-0. ISSN 1233-6688. DOI: $10.14746 /$ se.2015.37.22
\end{abstract}

The stage of the entry into teaching of the beginning teacher is a distinct stage in the circle of the professional development of teachers and is accompanied by many challenges and difficulties. The classic model of Fuller (1969) and its extension into the model of Fuller and Brown (1975) that addresses the beginning teacher's concerns, presents three stages in the beginning teacher's professional development: the stage of survival - concerns about the self, the stage of mastery - concerns about tasks/situations, and the stage of impact - concerns about the impact on students. This article seeks to present a research outline that addresses a population on which the research has not focused extensively, the novice teachers in special education, who work in the different frameworks of special education that present the novice teachers with challenges and difficulties. The research will examine what are the difficulties of the novice teachers in special education, in the different frameworks of special education, during the year of their entry into teaching. In addition, the research will examine whether there is a distinction between the different frameworks in the aspect of the difficulties with which the novice teachers cope, as well as in the solutions provided to them in coping with their difficulties. The importance of this research study is by extension the theoretical academic knowledge about the entry into teaching and the difficulties of beginning teachers in special education, and the possibility to use this knowledge to improve the mechanisms of absorption of the special education novice teachers in the educational field.

Key words: induction, novice teacher, difficulties of novice teacher, special education, the educational system in Israel 
The stage of the entry into the teaching profession is described in many research studies in the world and in Israel as the most important and significant period in the process of professional development of teachers ${ }^{1}$. The nature of the entry into the teaching profession influences the novice teachers' professional future, perception of their role, and nature of the formation of their professional identity ${ }^{2}$.

Alongside the professional and personal challenges that face the new teachers, the beginning of the path in teaching is described in the research literature as one of the complex, difficult, and critical periods during the career of teachers ${ }^{3}$, in which they are disturbed by problems of survival ${ }^{4}$. The beginning teachers have many diverse tasks ${ }^{5}$ and their coping with these roles may create disappointment, difficulties, frustration and burnout ${ }^{6}$. The difficulties that the novice teachers experience lead to the dropping out of many teachers from the educational system, even those who have the potential to excel ${ }^{7}$.

While the research literature on the topic of the entry into teaching and the difficulties of the beginning teachers is extensive, the research about the difficulties of the novice teachers in special education is sparse ${ }^{8}$. The literature indicates unique difficulties, which recur and with which the novice

${ }^{1}$ R.D. Fantilli, D.E. McDougall, A study of novice teachers: Challenges and supports in the first years, Teaching and Teacher Education, 2009, 25, p. 814; S. Zilbershtrom, the statement of the manager of the induction department, [in:] To Be a Teacher in the Path of Entry into Teaching, eds A. Schatz-Oppenheimer, D. Maskit, S. Zilbershtrom, Tel Aviv 2011, p. 9.

2 S. Zilbershtrom, The statement of the manager of the induction department, [in:] To Be a Teacher in the Path of Entry into Teaching, eds A. Schatz-Oppenheimer, D. Maskit, S. Zilbershtrom, Tel Aviv 2011, 9.

${ }^{3} \mathrm{H}$. Tam, Is the Support of Absorption Effective for the Professional Development of Beginning Teachers? Findings of a Longitudinal Research, Pages, 2005, 39, p. 66-67.

${ }^{4}$ R. Strahovsky, R. Hertz-Lazarowitz, L. Orland-Barak, Paths for Mentoring Teachers: Guide to the Perplexed, Tel Aviv 2008, p. 68.

${ }_{5}$ R. Starhovsky, A. Marbach, R. Hertz-Lazarowitz, The Beginning Teacher: Stations and Hurdles in the First Year of Teaching, Studies in Administration and Organization of Education, 2002, 26, p. 123.

${ }^{6}$ J.H.C. Vonk, Conceptualizing novice teachers professional development: A base for supervisory interventions, San Francisco, CA 1995, p. 4; R. Strahovsky, R. Hertz-Lazarowitz, L. OrlandBarak, Paths for Mentoring Teachers, p. 69.

7 L. Darling-Hammond, Keeping good teachers: Why it matters, what leaders can do, Educational Leadership, 2003, p. 7; S. Feiman-Nemser, What new teachers need to learn, Educational Leadership, 2003, 60, 8, p. 25; R.D. Fantilli, D.E. McDougall, A study of novice teachers, p. 814.

8 S.D. Whitaker, Needs of beginning special education teachers: Implications for teacher education, Teacher Education and Special Education, 2003, 26, 2, p. 107-108; C.C. Griffin et al., First-year special educators, the influence of school and classroom context factors on their accomplishments and problems, Teacher Education and Special Education, 2009, 32, 1, p. 45-46. 
teachers in special education cope with during their entry into teaching. These difficulties cause the departure of about half of the teachers of special education from the educational system in the first five years of their work ${ }^{9}$, while the number of the students with special needs, who need the services of special education, is steadily increasing ${ }^{10}$.

In Israel, the educational system implemented an inclusion model that advocates a sequence of frames - Inclusion, special education classes in the schools of general education and separate schools for special education ${ }^{11}$. Special education novice teachers, as well as the teachers of special education, are placed in one of these three types of frameworks:

1. The framework of inclusion in the general schools is for students that diagnosed as having special needs and study in the general classes. The inclusion students obtain few hours of weekly support from a special education teacher or a paramedical therapist, for the most part outside of the general class.

2. Special education classes in the schools of general education, in the framework of which the students learn all the study hours in a homogeneous class with a special education teacher. Individual students may be included in one, or in a number of subject studies in the classes of general education, according to their abilities. Every special education class is characterized according to a type of disorder.

3. The separate schools for special education are for students with complex disorders. Every school is characterized according to a type of disorder.

The literature indicates that emphasis is given in the existing research study to the difficulties of the novice teachers in the special education who work in the inclusion framework, and that there is no distinction between the different frameworks of special education in the aspect of the difficulties with which the novice teachers who work in them cope. Inclusion is the central approach today in education in the world and in Israel ${ }^{12}$. However, separate schools of special education and special education classes in the

9 B.S. Billingsley, Promoting teacher quality and retention in special education, Journal of Learning Disabilities, 2004, 37, 5, p. 371; R. Swanson, G. Murri, N. Murri, Beginning special educators' intent to stay in special education: Why they like it here, Teacher Education and Special Education, 2006, 29, 3, p. 179.

${ }^{10}$ R. Swanson, G. Murri, N. Murri, Beginning special educators'.

${ }^{11}$ C. Igel, S. Malichi, Special Education Law - Social, Value-Oriented, and Professional Reflection in the Shaping of Policy, [in:] Integrations: Learning with Handicaps in the Educational Systems, eds S. Reiter, Y. Lazer, G. Avisar, Haifa 2007, p. 148.

12 S. Reiter, Y. Lazar, G. Avisar, Editors words: Inclusiveness - From vision into practice, [in:] Inclusiveness: Learners with Handicaps in the Educational Systems, eds S. Reiter, Y. Lazar, G. Avisar, Haifa 2007, p. 9; M. Ainscow, S. Miles, Making education for all inclusive: Where next? Prospects, 2008, 38, 1, p. 16. 
schools of general education operate in the educational system in Israel ${ }^{13}$ and novice teachers are placed there routinely.

The research study outline that will be described in this article will examine the difficulties of the novice teachers in special education, who work in the different frameworks of special education, during their year of the entry into the teaching. In addition, the research study will examine whether there is a differentiation between the special education frameworks in which the special education novice teachers work, in the aspect of the difficulties with which they cope, as well as in the support provided to them when they deal with these difficulties.

Differential reference to the difficulties of the special education novice teachers is important in the aspect of the unique and relevant support provided to the secondary communities of the special education novice teachers so as to facilitate the year of their entry into teaching.

\section{The stage of induction of the beginning teacher}

The picture that arises from the literature about the novice teachers is almost universal ${ }^{14}$, according to which the transition from the status of a student of teaching to the status of a novice teacher is reported in the literature as sudden and dramatic ${ }^{15}$.

The novice teacher moves from a relatively protected and supporting environment, while he is a student teacher, to an independent experience that requires responsibility with the entry into teaching ${ }^{16}$. In this sharp transition, the novice teacher undergoes a process of socialization in two parallel dimensions: to the teaching profession and to the school where he is absorbed, which is an organization with a unique culture ${ }^{17}$.

${ }_{13}$ M. Marom et al., Inclusion of Special Needs Children in the Regular Educational System: A Review of the Literature, Jerusalem 2006, p. 9-10, 12-13.

${ }_{14}$ N. Sabar Ben-Yehoshua, Interpretative Analysis: From the Garden of Eden to Reality via Crisis - Novice Teachers as Emigrants, [in:] Geners and Traditions in Qualitative Research, ed. N. Sabar-Ben Yehoshua, Or Yehuda: Kinneret, Zmora-Bitan, 2001, p. 443.

${ }^{15} \mathrm{H}$. Tam, Is the Support of Absorption Effective for the Professional Development of Beginning Teachers? Findings of a Longitudinal Research, Pages, 2005, 39, p. 67; P. Nasser-Abu Alhija, R. Reichenberg, B. Fresco, The Process of Induction in Teaching - A Final Report, Tel Aviv 2006, p. 3.

16 S. Feiman-Nemser, What new teachers need to learn, p. 25; S.D. Whitaker, Needs of beginning special education teachers, p. 106; H. Tam, Is the Support of Absorption Effective, p. 67.

17 R. Lazovsky, R. Reichenberg, The new mandatory induction programme for all beginning teachers in Israel: Perceptions of inductees in five study tracks, Journal of Education for Teaching, 2006, 32, 1, p. 53; P. Nasser-Abu Alhija, R. Reichenberg, B. Fresco, The Process of Induction in Teaching, p. 4. 
The terms of 'first year shock' or 'reality shock' are concepts that appear in different forms in the research studies that address the beginning teacher ${ }^{18}$ and address the gap between the beginning teacher's expectations and the reality he encounters ${ }^{19}$. This gap is prominent because of the expectation of the schools that the novice teacher will function in all the dimensions of his work on a level of performance at least that of the experienced teachers ${ }^{20}$. This expectation is on the background of the novice teacher's existence under constant follow-up of principals and supervisors, for the purpose of the continuation of his employment and the receipt of tenure ${ }^{21}$. In this situation, the novice teacher feels in a situation of survival and invests considerable efforts to 'keep his head above water'22.

The novice teacher comes to the educational system with concerns but also with a feeling of enthusiasm. However, the extensive literature about the beginning teacher indicates that in the stage of the entry into teaching the novice teacher's coping with tasks and expectations intensifies his professional and personal difficulties that are prominent and frequent, and may create disappointment and burnout ${ }^{23}$.

Vonk (1995) ${ }^{24}$ developed a conceptual research-based framework that describes the main dimensions that comprise the process of professional development of the beginning teachers, through the identification of their main difficulties. The personal dimension which refers to the development of the teacher as a person ${ }^{25}$. In this dimension the novice teachers' difficulties entail feelings of frustration, exhaustion, powerlessness, loneliness, and lack of confidence $^{26}$. The professional dimension refers to the academic knowledge

${ }_{18}$ N. Sabar Ben-Yehoshua, Interpretative Analysis: From the Garden of Eden to Reality via Crisis - Novice Teachers as Emigrants, [in:] Geners and Traditions in Qualitative Research, p. 454; H. Tam, Is the Support of Absorption Effective, p. 66-67; R.D. Fantilli, D.E. McDougall, A study of novice teachers, p. 814; O. Schatz Oppenheimer, N. Dvir, From ugly duckling to swan: Stories of novice teachers, Teaching and Teacher Education, 2014, 37, p. 140.

${ }^{19}$ O. Schatz Oppenheimer, N. Dvir, From ugly duckling to swan, p. 141.

${ }^{20}$ R. Lazovsky, R. Reichenberg, The new mandatory induction programme, p. 53; R.D. Fantilli, D.E. McDougall, A study of novice teachers, p. 814.

${ }^{21}$ R. Strahovsky, R. Hertz-Lazarowitz, L. Orland-Barak, Paths for Mentoring Teachers, p. 68-69.

22 R.D. Fantilli, D.E. McDougall, A study of novice teachers, p. 814.

${ }^{23}$ L. Darling-Hammond, Keeping good teachers, p. 8-9; I. Harari, E. Eldar, H. Shechter, "With This I Came Home Today" - Significant Events in the Eyes of Novice Teachers (Interns) in Their First Year of Work, In Movement, 2007, 8, p. 336-337; R. Strahovsky, R. Hertz-Lazarowitz, L. OrlandBarak, Paths for Mentoring Teachers, p. 69.

${ }^{24}$ J.H.C. Vonk, Conceptualizing novice teachers professional development, p. 3, 7.

25 Ibidem, p. 8-9.

${ }^{26}$ R. Lazovsky, R. Reichenberg, The new mandatory induction programme, p. 53; O. Schatz Oppenheimer, N. Dvir, From ugly duckling to swan, p. 140. 
and professional skills ${ }^{27}$. This dimension is characterized by the difficulties of beginning teachers related to the planning and organization of the learning material, the scarcity of appropriate learning materials, the teaching in heterogeneous classes, the creation of motivation among the students, the choice of appropriate strategies for teaching, the evaluation of the learning, discipline problems, coping with individual problems of students, and the creation of a relationship with students and with parents. The ecological dimension ${ }^{28}$, in which the prominent difficulties of the beginning teacher are those related to the familiarity with the organizational climate of the school, the communication with colleagues, including the administration, the supervisors, and the other teachers, and the placement of the beginning teachers in the educational system ${ }^{29}$.

Most of the novice teachers consider their difficulties as personal and unique and find it difficult to see them as a part of the process of adjustment and professional development ${ }^{30}$.

\section{The professional development of teachers during their first year of work}

The professional development of the novice teachers is an ongoing process that occurs entirely during the year of entry into teaching and connects many different components into one picture.

In the literature, it is possible to find a variety of perceptions and approaches to the research of the professional development of beginning teachers. On the basis of these approaches, different models were built, which are the outcome of attempts that were undertaken over the years to create categorization of the stages of the development of the beginning teachers in the stage of the entry into teaching. The proposed models indicate on continues development trend during the stage of entry into teaching.

The most known model that relies on the traditional developmental approach is the model of Fuller (1969) ${ }^{31}$ and its extension in the model of Fuller

27 J.H.C. Vonk, Conceptualizing novice teachers professional development, p. 10-13.

${ }^{28}$ Ibidem, p. 9-10.

${ }^{29}$ L. Darling-Hammond, Keeping good teachers, p. 9, 12; S. Feiman-Nemser, What new teachers need to learn, p. 22-23; S.D. Whitaker, Needs of beginning special education teachers, p. 106107; I. Harari, E. Eldar, H. Shechter, "With This I Came Home Today", p. 337-338; R.D. Fantilli, D.E. McDougall, A study of novice teachers, p. 815.

30 O. Schatz Oppenheimer, N. Dvir, From ugly duckling to swan, p. 140.

31 F.F. Fuller, Concerns of teachers: A developmental conceptualization, American Education Research Journal, 1969, 6, p. 207-226. 
and Brown (1975) 32 . This model describes the professional development as occurring in a number of developmental stages. The main axis on which the model is built is the 'areas of concern' of the beginning teacher, areas in which the novice teacher's attention is focused. The model of Fuller (1969) and Fuller and Brown (1975) is characterized in that it is classic, continuous, and hierarchical ${ }^{33}$. According to this model, teachers at the beginning of their path undergo three stages of professional development: (1) the stage of survival - concerns about self, (2) the stage of mastery - concerns about tasks/situations. This stage focuses on the teaching strategies and skills. (3) The stage of impact - concerns about impact on students, their needs, emotions, and achievements ${ }^{34}$.

Fuller (1969) and Fuller and Brown (1975) assume a continuous and cumulative order of development stages. Successful teaching experiences and overcoming difficulties at any stage are a condition of the transition to the next stage ${ }^{35}$.

The model of Fuller (1969) and Fuller and Brown (1975) constitute the theoretical model upon which the present research study will rely, when it examines difficulties of special education novice teachers during their first year of work. This model has been chosen since it offers a developmental perception that provides a clear conceptualization of the problems and difficulties that beginning teachers experience with their entry into teaching.

The research studies that followed Fuller (1969) and Fuller and Brown (1975) found that the concerns of the teacher did not always advanced in a continuous developmental manner and claimed that it is possible to return to earlier stages in the development as dependent on the context and on the sudden requirements. Novice teachers may be found simultaneously in different stages at any given time as a result of different aspects of the position, so that there may be overlap between stages, and the beginning teacher may be troubled by topics related to a number of stages in parallel ${ }^{36}$. Therefore,

${ }^{32}$ F.F. Fuller, O.H. Brown, Becoming a teacher, [in:] Teacher Education, (The 74th yearbook of the national society for the study of education. Part 2), ed. K. Ryan, Chicago 1975, p. 25-52.

33 P.F. Conway, C.M. Clark, The journey inward and outward: A re-examination of Fuller's concerns-based model of teacher development, Teaching and Teacher Education, 2003, 19, p. 465.

${ }^{34}$ F.F. Fuller, Concerns of teachers, p. 220-221; F.F. Fuller, O.H. Brown, Becoming a teacher, [in:] Teacher Education, p. 37-40; P.F. Conway, C.M. Clark, The journey inward and outward, p. 466-467.

35 F.F. Fuller, Concerns of teachers, p. 223; G.D. Borich, Dimensions of self that influence effective teaching, [in:] The role of self in teacher development, eds R.P. Lipka, M. Brinthaupt, Albany 1999, p. 105.

${ }^{36}$ N. Amir, P. Tamir, Characteristic Needs, Ways, and Emphases in the Process of Entry into Teaching, [in:] Support in Absorption: From Experiment to Institutionalization, ed. D. Shachor, Tel Aviv 1995; G.D. Borich, Dimensions of self that influence effective teaching, [in:] The role of self, 
the present research study will broaden the observation of the difficulties of the special education novice teacher that suggested by Fuller (1969) and Fuller and Brown (1975) and will emphasize the multidimensional perspective of concerns and difficulties of the novice teacher in the year of induction.

\section{The difficulties of the novice teacher in special education}

The literature notes that novice teachers in special education have unique difficulties in the year of their entry into teaching. These difficulties are in addition to the difficulties that are similar to those of beginning teachers in general education ${ }^{37}$. The difficulties of the novice teachers in special education are expressed in a number of contexts: the context of policy, the school context, and the class context.

\section{The context of policy}

The inclusion of students with special needs in the general classes is the main approach today in teaching and education in Israel and around the world ${ }^{38}$. The inclusion approach enables students with special needs to learn in the frameworks of the classes of general education with appropriate support and resources. This approach derives from a broader trend of the inclusion of the special needs person in the community as a part of the valueoriented perception regarding the rights of every individual in a democratic society 39 .

p. 102-105; R. Starhovsky, A. Marbach, R. Hertz-Lazarowitz, The Beginning Teacher, p. 152-153; S. Strahovsky, R. Hertz-Lazarowitz, L. Orland-Barak, Paths for Mentoring Teachers: Guide to the Perplexed, Tel Aviv 2008, p. 97.

37 T.W. Busch et al., Teaching students with learning disabilities: Perceptions of a first-year teacher, Journal of Special Education, 2001, 35, p. 92; K.L. Kilgore et al., The problems of beginning special education teachers: Exploring the contextual factors influencing their work, Action in Teacher Education, 2003, 25, 1, p. 38; B.S. Billingsley, Promoting teacher quality, p. 46

38 S. Reiter, Y. Lazar, G. Avisar, Editors words: Inclusiveness - From vision into practice, [in:] Inclusiveness: Learners with Handicaps in the Educational Systems, eds S. Reiter, Y. Lazar, G. Avisar, Achva Press, Haifa 2007, p. 9; M. Ainscow, S. Miles, Making education for all inclusive: Where next?, Prospects, 2008, 38, 1, p. 16.

${ }^{39}$ C. Igel, S. Malichi, Special Education Law - Social, Value-Oriented, and Professional Reflection in the Shaping of Policy, [in:] Integrations: Learning with Handicaps in the Educational Systems, eds S. Reiter, Y. Lazer, G. Avisar, Achva Press, Haifa 2007, p. 145-147. 
The implementation and assimilation of inclusion in the educational system have made the role of the teachers of special education into a role that necessitates specialization on the topic of inclusion and abilities of partnership and cooperation, abilities that the novice teachers in special education must display alongside their coping with being new in the educational system and in their role as a teacher ${ }^{40}$. The reports of the novice teachers in special education indicate that the preparation they received during their period of training is not sufficient for this role ${ }^{41}$, and they are lack of knowledge about the policy of special education, about systemic information related to special education and its procedures ${ }^{42}$, and about knowledge and skills required for their role in inclusion ${ }^{43}$.

The regulations, procedural requirements, and required paperwork, which are derived from the legislation, from the implementation of the inclusion, and from the work of special education adjusted individually, are exaggerated in the opinion of the novice teachers in special education and constitute a source of difficulty for them ${ }^{44}$.

\section{The school context}

The school and organizational climate and the management style have influence on the achievements and difficulties of the novice teachers in special education at the beginning of their path. The novice teachers in special education sometimes feel distinct from general education exactly as their students are distinct ${ }^{45}$. The novice teachers feel isolated, and this influences the ability to access required resources and personnel ${ }^{46}$.

40 S.D. Whitaker, Needs of beginning special education teachers, p. 114; B.S. Billingsley, Promoting teacher quality, p. 373.

41 R. Swanson, G. Murri, N. Murri, Beginning special educators' intent to stay in special education, p. 187.

42 S.D. Whitaker, Needs of beginning special education teachers, p. 106-107, 111-112; B.S. Billingsley, Promoting teacher quality, p. 372.

43 B.S. Billingsley, Promoting teacher quality, p. 372; R. Swanson, G. Murri, N. Murri, Beginning special educators' intent to stay in special education, p. 188.

44 T.W. Busch et al., Teaching students with learning disabilities, p. 98; M.A. Mastropieri, Challenges encountered by first-year special education teachers, Journal of Special Education, 2001, 35, p. 69, 72; S.D. Whitaker, Needs of beginning special education teachers, p.107-108, 113; R. Swanson, G. Murri, N. Murri, Beginning special educators' intent to stay in special education, p. 180, 186.

45 C.C. Griffin et al., First-year special educators, the influence of school and classroom context factors on their accomplishments and problems, Teacher Education and Special Education, 2009, 32, 1, p. 47.

${ }^{46}$ K.L. Kilgore et al., The problems of beginning special education teachers: Exploring the contextual factors influencing their work, Action in Teacher Education, 2003, 25, 1, p. 38, 43-44. 
The novice teachers in special education understand that close relations with the teachers of general education are critical to the success of their students in the integration in general education. However, their colleagues from general education do not share this sense of responsibility ${ }^{47}$. Many schools of general education lack infrastructures for the inclusion of students with handicaps and routines of communication and schedule of shared work of teachers from general education and teachers from special education ${ }^{48}$.

In addition, the level of support that the novice teachers in special education receive from the school administration and the district is mentioned in the literature as a consistent factor that creates frustration, pressure, and lack of satisfaction and influences the novice teachers' decisions regarding the continuation of their career ${ }^{49}$. The research studies indicate that the novice teachers in special education report that the principals were often seen as lacking interest in the education of students with disabilities ${ }^{50}$.

\section{The class context}

The indices with influence on the achievements and difficulties of the novice teachers in special education at the beginning of their path related to their functioning in the class address the daily patterns of teaching, the teacher-student relations, and the availability of resources of time ${ }^{51}$.

The main roles of the special education teachers, as anchored also in law, are to provide adjusted teaching for their students and to build individualized education plans (IEPs) ${ }^{52}$. These roles present unique difficulties to the novice teachers in special education ${ }^{53}$ who report that they did not receive

${ }^{47}$ Ibidem, p. 38, 44-45; R. Swanson, G. Murri, N. Murri, Beginning special educators' intent to stay in special education, p. 186-187.

${ }^{48}$ K.L. Kilgore et al., The problems of beginning special education teachers, p. 38, 44.

${ }^{49}$ Ibidem, p. 38, 44-45; R. Swanson, G. Murri, N. Murri, Beginning special educators' intent to stay in special education, p. 180, 186; S.D. Whitaker, Needs of beginning special education teachers, p. 107-108.

${ }^{50}$ C.C. Griffin et al., First-year special educators, the influence of school, p. 46.

51 Ibidem, p. 59.

52 In Israel individualized education plans are built for every student with special needs who studies in the framework of general education and receives support in specific fields from the inclusion teacher. In the frameworks of special education, whether separate or those found in the framework of general education, a personal curriculum is built for every student in all areas of her functioning (Israel, Special Education Law, 1988).

53 T.W. Busch et al., Teaching students with learning disabilities, p. 95-96; M.A. Mastropieri, Challenges encountered by first-year special education teachers, p. 68; S.D. Whitaker, Needs of beginning special education teachers, p. 113. 
training for the writing of individualized plans ${ }^{54}$ and that they lack of materials for adjusted teaching 55 .

The findings of research studies show that the novice teachers in special education have the responsibility for too many students so that they cannot provide adjusted teaching necessary for every student ${ }^{56}$. The students under the responsibility of the special education novice teachers are at a broad and complex variety of levels, disabilities, and situations of functioning, and this range creates difficulty in effective teaching and in the effective implementation of the curriculum and the control of the behaviors. In addition, the novice teachers note, consistently, the lack of technical and scholastic resources $^{57}$, and this does not enable them effective teaching 58 .

The inclusion of special needs students in general education and the laws that were enacted in the spirit of the inclusion approach necessitate knowledge and access of the special education teacher to curricula of general education, to unique teaching methods, and to teaching areas of content learned in general education, which are not familiar to them ${ }^{59}$. This entails risk that the students with severe disorders, who need the greatest support, lose significant and critical learning opportunities ${ }^{60}$.

In addition, the novice teachers in special education also note difficulties that derive from the work with students who present complex behavioral challenges and difficulties in the control in the classroom, with which even experienced teachers have difficulties ${ }^{61}$.

${ }^{54}$ S.D. Whitaker, Needs of beginning special education teachers, p. 113.

55 M.A. Mastropieri, Challenges encountered by first-year special education teachers, p. 70, 7273; C.C. Griffin et al., First-year special educators, the influence of school, 1, p. 59.

56 K.L. Kilgore et al., The problems of beginning special education teachers: Exploring the contextual factors influencing their work, Action in Teacher Education, 2003, 25, 1, p. 43-45; C.C. Griffin et al., First-year special educators, the influence of school and classroom context factors on their accomplishments and problems, Teacher Education and Special Education, 2009, 32, 1, p. 59.

57 T.W. Busch et al., Teaching students with learning disabilities, p. 94, 98; V. MacDonald, D.L. Speece, Making time: A teacher's report on her first-year of teaching children with emotional disabilities, Journal of Special Education, 2001, 35, p. 86-87; S.D. Whitaker, Needs of beginning special education teachers, p. 106, 108, 111.

58 K.L. Kilgore et al., The problems of beginning special education teachers: Exploring the contextual factors influencing their work, Action in Teacher Education, 2003, 25, 1, p. 38, 43-44; C.C. Griffin et al., First-year special educators, the influence of school, 1, p. 46.

59 M.A. Mastropieri, Challenges encountered by first-year special education teachers, p. 68-69; R. Swanson, G. Murri, N. Murri, Beginning special educators' intent to stay in special education, p. $179-180,187,189$.

60 S.D. Whitaker, Needs of beginning special education teachers, p. 107; B.S. Billingsley, Promoting teacher quality, p. 370.

${ }^{61}$ T.W. Busch et al., Teaching students with learning disabilities, p. 92, 98; V. MacDonald, D.L. Speece, Making time, p. 85; M.A. Mastropieri, Challenges encountered by first-year special education teachers, p. 68, 71, 73; K.L. Kilgore et al., The problems of beginning special education 
The combination of lack of experience, commitment to many challenging tasks, the increase of procedures, processes, and paperwork, the need to provide teaching adjusted to many students with complex and multiple disorders, and the need for work with colleagues from general education, create a load at work for the novice teachers in special education and difficulty in control and planning their time ${ }^{62}$. The novice teachers are torn between critical teaching assignments and onerous bureaucratic requirements. They invest considerable efforts, their teaching time is reduced, and they lack time that will allow them to play a significant part in collaborations with their colleagues, which they greatly need ${ }^{63}$.

These difficulties that the special education novice teachers experienced lead them to feel frustration, stress, and lack of effectiveness at work ${ }^{64}$.

\section{The research outline}

The present research study that addresses difficulties of special education novice teachers in their induction year, in different special education frameworks, designed according to a research methodology that relies on the qualitative-constructivist paradigm that seeks to examine reality in its complexity and its multiplicity of facets, and which assumes that "phenomena can be understood only from an internal perspective of those who experience it" 65 .

This research study seeks to put in the main place the novice teachers in special education who work in the three types of frameworks of special education in Israel: Inclusion in general schools, special education classes in general schools and special education schools. However, the research study will also examine the perceptions of policy makers in the field of the induction and special education, by semi-structured interviews, and the documents published by them in the topic of induction, as representing the su-

teachers: Exploring the contextual factors influencing their work, Action in Teacher Education, 2003, 25,1, p. 45.

62 T.W. Busch et al., Teaching students with learning disabilities, p. 98; V. MacDonald, D.L. Speece, Making time, p. 87; S.D. Whitaker, Needs of beginning special education teachers, p. 108; B.S. Billingsley, Promoting teacher quality, p. 372-373; R. Swanson, G. Murri, N. Murri, Beginning special educators' intent to stay in special education, p. 179, 189; C.C. Griffin et al., Firstyear special educators, the influence of school, 1, p. 46.

63 B.S. Billingsley, Promoting teacher quality, p. 372.

${ }^{64}$ Ibidem; R. Swanson, G. Murri, N. Murri, Beginning special educators' intent to stay in special education, p. 180;

65 A. Shkedi, Words of Meaning: Qualitative Research - Theory and Practice, Tel Aviv 2015, p. 36. 
preme rationale of the educational system, so as to further the depth of the research and enable its broader perspective.

The perceptions of the special education novice teachers about their difficulties will examine at three points of time in their first year of work: in the beginning of the school year, by semi-structured interviews, at the end of the first half of the school year, by an open questionnaire, and in the period of the end of the school year, by semi-structured interviews. The choice of these three points of time follows the researches of Fuller (1969) and Fuller and Brown (1975), upon which this research is based, presenting a theoretical model of three stages that examines the concerns of the beginning teachers.

The various perspectives and the research tools for the data collection will allow to triangulate and thus to present a broad research picture from different angles that seek to complete one another.

Grounded theory is the research method that will be used in the present research study. Analysis of the data will be performed through content analysis that will be constructed inductively, out of the transcriptions of the interviews, the open questionnaire, and the documents. The analysis will provide a complete explanation of the researched phenomenon, which will be obtained by the research participants themselves and which can be generalized and integrated with the theoretical knowledge that described in the literature ${ }^{66}$.

\section{Summary}

The article reviewed in short the main points of research studies that address the stage of the entry into teaching, the difficulties of beginning teachers and the difficulties of novice teachers in special education. The article presented the model of the professional development of beginning teachers formulated by Fuller (1969) and of Fuller and Brown (1975), a model that addresses the concerns of novice teachers. This theoretical model will constitute the base model of the present research study, with its extension following the conclusions of later research studies.

In addition, this article presented an outline for a new research study that seeks to examine the difficulties of novice teachers in special education in the different frameworks of special education in Israel, during the year of their entry into teaching. The differentiation of unique difficulties of novice

${ }^{66} \mathrm{Y}$. Ayalon, N. Sabar Ben-Yehoshua, The process of content analysis according to the grounded theory, [in:] Data analysis in qualitative research, eds L. Kacen, M. Kromer-Nevo, Beer-Sheva 2010, p. 364, 367, 374; A. Shkedi, Words of Meaning, p. 155-168. 
teachers according to the different frameworks of special education may contribute to the extension of the theoretical research knowledge about the special education novice teachers, their difficulties in the different frameworks of special education, their ways of coping on the continuum of the induction year. From the practical aspect the study may contribute to reexamination of the perceptions, policy, and translation from theory into practice for the improvement of the tools and the support that the educational system provides to its novice teachers who work in the different frameworks of special education. In addition, the study may contribute to introduction of necessary changes in the outline of the programs of teacher education for special education. These changes will enable the inculcation of knowledge, tools, and skills for the student teachers in their way to the field of education, and thus will give a solution already in the period of training for some of the unique difficulties with which the special education novice teachers cope. These may bring about the retention of the novice teachers in special education and the promotion of students with special needs in particular.

\section{BIBLIOGRAPHY}

Ainscow M., Miles S., Making education for all inclusive: Where next? Prospects, Quarterly Review of Comparative Education, 2008, 38, 1.

Amir N., Tamir P., Characteristic Needs, Ways, and Emphases in the Process of Entry into Teaching, [in:] Support in Absorption: From Experiment to Institutionalization, ed. D. Shachor, Mofet Institute, Ministry of Education, Tel Aviv 1995. [in Hebrew]

Ayalon Y., Sabar Ben-Yehoshua N., The process of content analysis according to the grounded theory, [in:] Data analysis in qualitative research, eds L. Kacen, M. Kromer-Nevo, BenGurion University of the Negev Press, Beer-Sheva 2010. [in Hebrew]

Billingsley B.S., Promoting teacher quality and retention in special education, Journal of Learning Disabilities, 2004, 37, 5.

Borich G.D., Dimensions of self that influence effective teaching, [in:] The role of self in teacher development, eds R.P. Lipka, M. Brinthaupt, State University of NY, Albany 1999.

Busch T.W., Pederson K., Espin C.A., Weissenburger J.W., Teaching students with learning disabilities: Perceptions of a first-year teacher, Journal of Special Education, 2001, 35.

Conway P.F., Clark C.M., The journey inward and outward: A re-examination of Fuller's concerns-based model of teacher development, Teaching and Teacher Education, 2003, 19.

Darling-Hammond L., Keeping good teachers: Why it matters, what leaders can do, Educational Leadership, 2003, 60.

Fantilli R.D., McDougall D.E., A study of novice teachers: Challenges and supports in the first years, Teaching and Teacher Education, 2009, 25.

Feiman-Nemser S., What new teachers need to learn, Educational Leadership, 2003, 60, 8.

Fuller F.F., Concerns of teachers: A developmental conceptualization, American Education Research Journal, 1969, 6. 
Fuller F. F., Brown O. H., Becoming a teacher, [in:] Teacher Education, (The 74th yearbook of the national society for the study of education. Part 2), ed. K. Ryan, University of Chicago Press, Chicago 1975.

Griffin C.C., Kilgore K.L., Winn J.A., Otis-Wilborn A., Hou W., Garvan C.W., First-year special educators, the influence of school and classroom context factors on their accomplishments and problems, Teacher Education and Special Education, 2009, 32, 1.

Griffin C.C., Winn J., Otis-Wilborn A., Kilgore K., New teacher induction in special education, Center on Personnel Studies in Special Education, Gainesville, FL 2003.

Harari I., Eldar E., Shechter H., "With This I Came Home Today" - Significant Events in the Eyes of Novice Teachers (Interns) in Their First Year of Work, In Movement, 2007, 8. [in Hebrew]

Igel C., Malichi S., Special Education Law - Social, Value-Oriented, and Professional Reflection in the Shaping of Policy, [in:] Integrations: Learning with Handicaps in the Educational Systems, eds S. Reiter, Y. Lazer, G. Avisar, Achva Press, Haifa 2007. [in Hebrew]

Kilgore K.L. Griffin C.C., Otis-Wilborn A., Winn J., The problems of beginning special education teachers: Exploring the contextual factors influencing their work, Action in Teacher Education, 2003, 25, 1.

Lazovsky R., Reichenberg R., The new mandatory induction programme for all beginning teachers in Israel: Perceptions of inductees in five study tracks, Journal of Education for Teaching, 2006, 32, 1.

MacDonald V., Speece D.L., Making time: A teacher's report on her first-year of teaching children with emotional disabilities, Journal of Special Education, 2001, 35.

Marom M., Bar-Simon Tov K., Kron A., Koren P., Inclusion of Special Needs Children in the Regular Educational System: A Review of the Literature, The Center for the Research of Social Policy in Israel Press, Jerusalem 2006. [in Hebrew]

Mastropieri M.A., Challenges encountered by first-year special education teachers, Journal of Special Education, 2001, 35.

Nasser-Abu Alhija P., Reichenberg R., Fresco B. The Process of Induction in Teaching A Final Report, Bet Berl College and Tel Aviv University, Tel Aviv 2006. [in Hebrew]

Reiter S., Lazar Y., Avisar G., Editors words: Inclusiveness - From vision into practice, [in:] Inclusiveness: Learners with Handicaps in the Educational Systems, eds S. Reiter, Y. Lazar, G. Avisar, Achva Press, Haifa 2007. [in Hebrew]

Schatz Oppenheimer O., Dvir N., From ugly duckling to swan: Stories of novice teachers, Teaching and Teacher Education, 2014, 37.

Shkedi A., Words of Meaning: Qualitative Research - Theory and Practice, Ramot Press, Tel Aviv 2015. [in Hebrew]

Special Education Law, State of Israel, 5748-1988. [in Hebrew]

Strahovsky R., Hertz-Lazarowitz R., Orland-Barak L., Paths for Mentoring Teachers: Guide to the Perplexed, Mofet Institute, Tel Aviv 2008. [in Hebrew]

Starhovsky R., Marbach A., Hertz-Lazarowitz R., The Beginning Teacher: Stations and Hurdles in the First Year of Teaching, Studies in Administration and Organization of Education, 2002, 26. [in Hebrew]

Swanson R., Murri G., Murri N., Beginning special educators' intent to stay in special education: Why they like it here, Teacher Education and Special Education, 2006, 29, 3.

Tam H., Is the Support of Absorption Effective for the Professional Development of Beginning Teachers? Findings of a Longitudinal Research, Pages, 2005, 39. [in Hebrew] 
Vonk J.H.C., Conceptualizing novice teachers professional development: A base for supervisory interventions, Paper presented at the Annual Meeting of the American Educational Research Association, San Francisco, CA 1995.

Whitaker S.D., Needs of beginning special education teachers: Implications for teacher education, Teacher Education and Special Education, 2003, 26, 2.

Zilbershtrom S., The statement of the manager of the induction department, [in:] To Be a Teacher in the Path of Entry into Teaching, eds A. Schatz-Oppenheimer, D. Maskit, S. Zilbershtrom, Mofet Institute, Tel Aviv 2011. [in Hebrew] 